\title{
Does Finance Promote Growth In Botswana?
}

\author{
Michael Adusei ${ }^{1, *}$ \\ ${ }^{1}$ Dept. of Accounting and Finance, Kwame Nkrumah University of Science and Technology, \\ Kumasi, Ghana \\ *Correspondence: Dept. of Accounting and Finance, Kwame Nkrumah University of Science \\ and Technology, PMB, KNUST Post Office, Kumasi, Ghana \\ E-mail: madusei10@yahoo.com
}

Received: February 26, 2013

Accepted: April 21, 2013 Published: June 6, 2013

doi:10.5296/rae.v5i2.3821

URL: http://dx.doi.org/10.5296/rae.v5i2.3821

\begin{abstract}
The discourse on the finance-growth connection is yet to be laid to rest. This paper contributes to the discourse by analyzing data (1981-2010) from Botswana. The paper uses Fully Modified Ordinary Least Squares regression technique and Pairwise Granger Causality for analysis. The results show that when domestic credit to the private sector as a share of GDP is used to proxy financial development, there is a negative, significant relationship between financial development and economic growth in Botswana. However, when the ratio of liquid liabilities (M3) to GDP is used to measure financial development, a positive, significant relationship is found. Pairwise Granger Causality test results reveal that economic growth Granger-causes a reduction in financial development when domestic credit to GDP ratio is used to proxy financial development. On the other hand, when M3 to GDP is used to proxy financial development, finance precedes growth. The paper, therefore, argues that finance may promote growth in Botswana via the expansion of the size of the financial intermediary sector.
\end{abstract}

Keywords: Botswana; financial development; economic growth 


\section{Introduction}

The role of finance in economic growth has attracted a great deal of intellectual scrutiny. The theoretical postulation is that finance could catalyze economic growth if funds are allocated to entrepreneurs who have viable entrepreneurial ideas but lack the needed funds to pursue them (Schumpeter, 1911). Empirically, an avalanche of studies has been done to investigate the relationship between finance and economic growth. Generally, the accumulating evidence kinks towards a significant relationship but the nature of the relationship as well as the direction of causality has remained the bone of contention. Whereas some studies have found a positive significant relationship between finance and growth (Tran, 2008; Hondroyiannis et al., 2004; Levine et al., 2000; King and Levine, 1993a and 1993b), others have reported evidence of a negative significant relationship between financial development and economic growth (Adusei, 2012; Loayza and Rancie're, 2006; Gourinchaset al. 2001; Demirguc-Kunt and Detragiache, 2000; Kaminsky and Reinhart, 1999). Regarding the direction of causality between finance and growth, three categories of findings are identifiable: supply-leading response group which posits that financial development leads to economic growth supported by notable studies such as Bittencourt (2012); Levine et al.(2000); and Choe and Moosa (1999); demand-following group underpinned by studies such as Odhiambo (2004, 2010); Zang and Kim(2007); Liang and Teng (2006); and Demetriades and Hussein (1996) which argues that growth leads to financial development; and bidirectional group grounded by the studies of Apergiset al.(2007); Rousseau and Vuthipadadorn (2005); Luintel and Khan (1999); Akinboade (1998); and Wood (1993) which submits that there is a bidirectional causality between financial development and economic growth.

The current study contributes to the current debate on the finance-growth connection with evidence from Botswana, one of the countries in Southern Africa. It draws inspiration from the growing contention that investigation into finance-growth nexus should be narrowed down to country-specific, time series studies which provide the opportunity to account for country-specific conditions (Bittencourt, 2012; Arestis and Demetriades, 1997).

The current study differs from the previous ones in Botswana (Eita and Jordaan, 2010; Akinboade, 1998) and, thus, should provide a fresh insight into the finance-growth nexus in Botswana in two ways. First, it uses current data (1981-2010). Second, it uses different measures of economic growth and financial development. Unlike Akinboade (1998)'s study that uses non-mineral GDP, the current study uses total real GDP per capita as proxy for economic growth. Unlike the studies of Eita and Jordaan (2010) and Akinboade (1998), two proxies of financial development are used: The ratio of liquid liabilities to GDP (or M3/GDP) is used to measure the overall size of the financial intermediary sector in Botswana whilst the ratio of domestic credit to the private sector to GDP is used to measure the level of financial services in Botswana. Whereas Eita and Jordan (2010) use the ratio of M2 to total GDP, the ratio of deposit liabilities to total nominal GDP, the ratio of credit extended to the private sector to total nominal GDP as proxies for financial development, Akinboade (1998) uses bank deposit liabilities to non-mineral nominal GDP and bank claims on the private sector to nominal non-mineral GDP as measures of financial development. 
The rest of the paper is sectionalized as follows. The next section reviews the extant literature followed by estimation results. Conclusion and policy implications section ends the paper.

\section{Literature Review in the African Context}

The finance-growth nexus has received some attention in Africa albeit inconclusive results. Agbetsiafa (2004) employs data from eight Sub-Saharan countries (Ghana, Ivory Coast, Kenya, Nigeria, Senegal, South Africa, Togo, and Zambia) to investigate the finance-growth nexus and reports that financial development and economic growth are cointegrated in the long run. In terms of direction of causality, the study reports that there is mostly a unidirectional causality running from financial development to economic development in Ghana, Nigeria, Senegal, South Africa, Togo, and Zambia. Different measures of financial development produce a bi-directional causality in Kenya, Zambia, Zambia, South Africa, Nigeria, Ghana, and Togo. Ndebbio (2004) examines financial deepening, economic growth and development for Sub-Saharan African countries and reports that a developed financial sector spurs overall growth of an economy. Esso (2010) also examines the finance-growth connection with focus on Burkina Faso, Cape Verde, Cote d'Ivoire, Ghana, Liberia and Sierra Leone and establishes a long-run relationship between the two variables. The study reveals that financial development precedes economic growth in Ghana and Mali, growth leads finance in Burkina Faso, Cote d'Ivoire and Sierra Leone, and finance and growth cause each other in Cape Verde and Liberia.

Odhiambo (2004) uses three proxies of financial development (the ratio of M2 to GDP, the ratio of currency to narrow money and the ratio of bank claims on the private sector to GDP) with real GDP per capita as proxy for economic growth to investigate the role of financial development in economic growth in South Africa and reports that economic growth leads financial development. Odhiambo (2010) revisits the finance-growth nexus in South Africa by looking at the dynamic causal relationship between financial development, investment and economic growth and shows evidence in support of demand-following hypothesis (i.e. economic growth leads financial development). However, this finding has since been contradicted by Adusei (2012) who uses time series data (1965 to 2010) with domestic credit as a share of GDP and broad money supply as a share of GDP as measures of financial development with real per capita GDP as proxy for economic growth and finds that finance undermines growth in South Africa and that there is a unidirectional causal relationship that runs from financial development to economic growth.

Odhiambo (2005) investigates the finance-growth connection in Tanzania. The study shows that there is a bi-directional causality between financial development and economic growth. The meaning is that finance and growth cause each other.

Quartey and Prah (2008) study the finance-growth connection in Ghana and show that whereas there is some evidence in support of demand-following hypothesis when growth in broad money to GDP ratio is used as a measure of financial development, there is no significant evidence to support either the supply-leading hypothesis or demand-following 
hypothesis when growth in domestic credit to GDP ratio, private credit to GDP ratio and private credit to domestic credit ratio are used as proxies for financial development. However, in a recent study in Ghana, Adusei (2013) finds evidence in support of supply-leading hypothesis using broad money supply as proxy for financial development.

Odhiambo (2009) analyzes the direction of causality between financial development and economic growth in Kenya. The study examines the effect of inflation on the finance-growth nexus and reports that economic growth Granger-causes financial development in Kenya regardless of whether the causality is estimated in a bivariate framework or in a trivariate setting.

Chukwu and Agu (2009) report from Nigeria that evidence exists in support of demand-following hypothesis in Nigeria when financial depth is proxied by banking sector's private sector credit and real broad money supply and supply-leading hypothesis when loan deposit ratio and bank deposit liabilities are used as proxies for financial depth. Enisan and Olufisayo (2009) also examine the finance-growth nexus in Nigeria with focus on the stock market and demonstrate that there is weak evidence in support of demand-following hypothesis using market size as indicator of stock market development. Ndako (2010) also analyzes the finance-growth nexus in Nigeria and reports that there is a unidirectional causality from financial development to economic growth (supply-leading) when bank credit to the private sector ( $\mathrm{LBCP}$ ) is used as a measure of financial development and a bidirectional relationship between financial development and economic growth when domestic credit to the private sector (LDCP) and bank deposit liabilities (LBDL) are used to proxy financial development.

In Botswana, the finance-growth connection has received some attention. Notably, Akinboade (1998) examines the causal relationship between financial development and economic growth in Botswana for the 1972-1995 using non-mineral real GDP per capita as proxy for economic growth as well as ratio of bank claims on the private sector to nominal non-mineral GDP and ratio of bank deposit liabilities to non-mineral GDP as proxies for financial development. The study reports bi-directional causality between financial development and economic growth. Eita and Jordaan (2010) also analyze the causal relationship between financial development and economic growth in Botswana for the period 1977-2006 and show that there is a stable long-run relationship between financial development and economic growth. They provide evidence of supply leading and demand-leading views of finance-growth nexus.

\section{Method}

\subsection{Model}

Economic growth is the dependent variable in our model and is defined as the logarithm of real per capita GDP (LGDPPC). Financial development is the independent variable. Two measures of financial development are used in our model. The ratio of domestic credit to the private sector to GDP (DCPS) is used to measure the level of financial services (e.g. Beck et al., 2000; Levine et al., 2000; Levine and Zervos, 1996; King and Levine 1993a) and the ratio 
of liquid liabilities to GDP (or M3/GDP) (LM3) is used to measure the overall size of the financial intermediary sector (e.g. Saciet al., 2009; Rioja and Valev 2004; Rousseau and Wachtel 2000; Levine et al., 2000; King and Levine 1993a; Goldsmith 1969). We include economic openness (LOPEN) and size of government (LGS) as control variables. Economic openness is defined as exports plus imports divided by GDP. Size of government is defined as logarithm of government consumption of goods and services as a share of GDP. All data are log-transformed.

The impact of financial development on economic growth is defined as:

$$
\text { yit }=\beta 1 \text { yit }-1+\beta 2 \text { Fit }+\varepsilon \text { it }
$$

Where $\mathrm{y}$ is the logarithm of per capita GDP, $F$ represents the explanatory variables and $\varepsilon_{\mathrm{it}}$ represents the error term.

\subsection{Data Source}

Annual time series data from Botswana covering the period 1981-2010 gathered from the World Development Indicators (WDI) of the World Bank (http://www.worldbank.org) have been used. The selection of the study period has been based on availability of data needed for analysis.

\section{Results}

Table 1 reports the results of the Augmented Dickey-Fuller (ADF) and Phillip-Perron (PP) unit root tests. The results indicate that all the variables are stationary at their $1^{\text {st }}$ difference form. These results satisfy the condition for performing cointegration analysis. Johansen Cointegration test is, therefore, performed. Lag length of VAR model is selected at 3 on the basis of Akaike Information Criterion (AIC), Schwarz criterion, Final Prediction Error and Hannan-Quinn Information Criterion. The results are reported in Table 2. As can be observed, there are four cointegrating relationships among the five variables (LCPS, LGDPPC, LGS, LM3, and LOPEN) in our model.

Table 1: ADF and PP Tests Results

\begin{tabular}{lllllll}
\hline \multicolumn{3}{c}{ ADF TEST } & \multicolumn{2}{c}{ PP TEST } \\
\hline Variables & $\begin{array}{l}\text { Test } \\
\text { Statistic }\end{array}$ & Lags & $\begin{array}{l}\text { Order of } \\
\text { integration }\end{array}$ & $\begin{array}{l}\text { Test } \\
\text { Statistic }\end{array}$ & Bandwidth & $\begin{array}{l}\text { Order of } \\
\text { integration }\end{array}$ \\
\hline LCPS & -1.22 & 3 & & -0.96 & 2 & \\
$\Delta$ LCPS & $-5.52^{* * *}$ & 6 & $\mathrm{I}(1)$ & $-3.76^{* *}$ & 2 & $\mathrm{I}(1)$ \\
LGDPPC & -0.54 & 0 & & -0.54 & 0 & \\
$\Delta$ LGDPPC & $-4.58^{* * *}$ & 0 & $\mathrm{I}(1)$ & $-4.56^{* * *}$ & 3 & $\mathrm{I}(1)$ \\
LGS & -2.0 & 0 & & -1.91 & 1 & \\
$\Delta$ GS & $-6.37^{* * *}$ & 0 & $\mathrm{I}(1)$ & $-7.30^{* * *}$ & 10 & $\mathrm{I}(1)$ \\
LM3 & -0.46 & 0 & & -0.58 & 1 & \\
$\Delta$ LM3 & $-4.32^{* * *}$ & 0 & $\mathrm{I}(1)$ & $-4.31^{* * *}$ & 1 & $\mathrm{I}(1)$ \\
LOPEN & -0.80 & 0 & & -0.65 & 2 & \\
$\Delta$ LOPEN & $-6.33^{* * *}$ & 0 & $\mathrm{I}(1)$ & $-6.36^{* * *}$ & 1 & $\mathrm{I}(1)$ \\
\hline
\end{tabular}

Notes: Reject at $10 \%(*), 5 \%(* *)$ and $1 \%(* * *)$ significance levels 
Table 2: Johansen and Maximum Likelihood Test for Cointegration

\begin{tabular}{llllllll}
\hline Hypotheses & $\begin{array}{l}\text { Trace } \\
\text { Test }\end{array}$ & $\begin{array}{l}5 \% \\
\text { critical } \\
\text { value }\end{array}$ & p-value & Hypotheses & $\begin{array}{l}\text { Max. } \\
\text { Eigen } \\
\text { Value }\end{array}$ & $\begin{array}{l}5 \% \\
\text { critical } \\
\text { value }\end{array}$ & - value \\
\hline $\mathrm{R}=0$ & 384.03 & 69.8190 & 0.0001 & $\mathrm{R}=0$ & 250.32 & 33.877 & 0.0001 \\
$\mathrm{R}=1$ & 133.71 & 47.856 & 0.0000 & $\mathrm{R}=1$ & 59.863 & 27.584 & 0.0000 \\
$\mathrm{R}=2$ & 73.849 & 29.797 & 0.0000 & $\mathrm{R}=2$ & 43.379 & 21.132 & 0.0000 \\
$\mathrm{R}=3$ & 30.470 & 15.495 & 0.0001 & $\mathrm{R}=3$ & 28.427 & 14.265 & 0.0002 \\
$\mathrm{R}=4$ & 2.0425 & 3.8415 & 0.1530 & $\mathrm{R}=4$ & 2.0425 & 3.8415 & 0.1530 \\
\hline
\end{tabular}

Table 3 provides the results of the regression analysis. The adjusted $\mathrm{R}^{2}$ is 0.97 , indicating a tight fit. The significance of the F-Statistic reported in Table 3 means that the explanatory variables jointly and significantly explain the dependent variable. The Durbin-Watson Test Statistic of 2.39 suggests that there is no autocorrelation in the sample. The ARCH test also suggests that there is no serial correlation in the data. The results of these diagnostic tests suggest appropriateness of our model.

Table 3 shows that financial development proxied by domestic credit to private sector as a share of GDP (LCPS) is negatively related to economic growth; meaning as more credit is channeled to the private sector, the economic growth of Botswana is undermined. Falling in tandem with findings from similar studies in Africa (Adusei, 2012; Adusei, 2013), the finding contradicts the findings of Akinboade (1998) and Eita and Jordaan (2010) who report bi-directional causality between financial development and economic growth in Botswana. Our finding supports the prognosis of the banking and currency crisis literature (e.g., Gourinchas et al., 2001; Demirguc-Kunt and Degatriache, 2000; Kaminsky and Reinhart, 1999). It dovetails into the observation made by Ben Naceur and Ghazouani (2003) that credit allocation negatively affects growth in developing countries over 1979-1999 because a high value of credit to the private sector, in cases of over-lending or careless lending, could actually result in a reduction in economic growth, since such lending is accompanied by high, but less efficient, investment (De Gregorio and Guidotti, 1995). A combination of channels could account for over-lending or careless lending. These include a limited monitoring capacity of regulatory agencies, lax supervision, the inability of banks to distinguish between good and bad projects during investment booms, the presence of an explicit or implicit insurance against banking failures, lack of skills in the banking personnel, repeated and substantial interventions by the government leading to moral hazard problems (Schneider and Tornell, 2004; Brownbridge and Kirkpatrick, 2000; De Gregorio and Guidotti, 1995). The results of the Granger causality tests reported in Table 4 show the direction of causality between domestic credit to private sector as share of GDP and economic growth. It is observable that there is unidirectional causality from economic growth to financial development when domestic credit to private sector as a share of GDP is used as proxy for financial development, suggesting that economic growth Granger-causes a reduction in financial development. What explains this puzzling result? The reason may lie in fiscal irresponsibility that emanates from resource abundance. Botswana is rich in mineral resources. Huge revenue from these minerals might have enriched the elite, created white 
elephant projects and fuelled inflation thereby undermining the growth of the financial sector. Thus, the mineral-driven growth will have a negative impact on the financial sector. Indeed, resource endowment could be a curse for a nation, depending on how the resource is managed. In some cases, countries such as Nigeria have experienced civil strife partly due to natural resources. Bloch et al. (2004) report that gargantuan oil revenue in the Middle East triggered a sudden expansion of domestic spending by about $50 \%$ between 1974 and 1979.Venezuela has chalked over US\$600 billion in oil revenue since the 1970s, but the real per capitaincome of her citizens dropped by 15\% between 1973 and 1985 (Bloch et al., 2004).

Most of the empirical studies report that M3/GDP which measures the financial intermediary size has a positive, significant relationship with economic growth (e.g. Beck and Levine 2002; Levine et al., 2000; Rousseau and Wachtel, 2000). Evidence in Table 3 shows that financial development proxied by broad money supply as a share of GDP is positively related to economic growth. Thus, our result is in line with the above-mentioned studies. The implication is that as the size of the financial intermediary sector of Botswana increases, economic growth is promoted. Table 4 shows that when M3/GDP is used to proxy financial development, supply-following hypothesis is confirmed. This suggests to us that financial development supports growth in Botswana via the expansion of the financial intermediary sector.

The growth literature emphasizes the importance of openness to international trade, both as a means of achieving the transfer of technical progress and as an engine of growth (Saci et al., 2009; Zang and Kim, 2007; Ghosh and Phillips, 1998; King and Levine, 1993a) Table 3 provides evidence to the effect that economic openness of Botswana is likely to accelerate her economic growth. Thus, the evidence in the literature is validated.

Table 3: FMOLS Regression Results

\begin{tabular}{|c|c|c|c|}
\hline \multicolumn{4}{|c|}{ Dependent variable $=$ LGDPPC } \\
\hline Variable & Coefficient & t-statistic & $\mathrm{p}$-value \\
\hline Constant & 2.492944 & 0.932496 & 0.3608 \\
\hline GDPPC(-1) & 0.900948 & 8.927221 & $0.0000 * * *$ \\
\hline LCPS & -0.298916 & -2.485812 & $0.0206^{* *}$ \\
\hline LM3 & 0.331431 & 1.959081 & $0.0623 *$ \\
\hline LOPEN & 0.331431 & 1.959081 & $0.0623^{*}$ \\
\hline LGS & -0.022237 & -0.083244 & 0.9344 \\
\hline Adjusted $\mathrm{R}^{2}=0.97$ & \multicolumn{3}{|c|}{ F-Statistic $=159.77(0.0000)$ ARCH Test $=$} \\
\hline $0.9937(0.8028)^{1} \mathrm{~N}=30$, & rbin-Watsor & & \\
\hline
\end{tabular}

${ }^{1=}$ Figures in parenthesis are probability values. Note***,**,* represent $1 \%, 5 \%$ and $10 \%$ significance levels respectively. 
Table 4: Pairwise Granger Causality Tests Lags:3

\begin{tabular}{lccc}
\hline Null Hypothesis: & Obs & F-Statistic & p-vlaue \\
\hline LCPS does not Granger Cause LGDPPC & 27 & 0.70761 & 0.55871 \\
LGDPPC does not Granger Cause LCPS & & 3.85133 & $0.02516^{* *}$ \\
LM3 does not Granger Cause LGDPPC & 27 & 2.34143 & $0.10391^{*}$ \\
LGDPPC does not Granger Cause LM3 & & 0.45713 & 0.71524 \\
\hline
\end{tabular}

Note $* * *, * *, *$ represent $1 \%, 5 \%$ and $10 \%$ significance levels respectively.

\section{Conclusion and Policy Implications}

The paper uses Fully Modified Ordinary Least Squares regression technique and Pairwise Granger Causality for analysis. The results show that when domestic credit to the private sector as a share of GDP is used to proxy financial development, there is a negative, significant relationship between financial development and economic growth in Botswana. However, when the ratio of liquid liabilities (M3) to GDP is used to measure financial development, a positive, significant relationship is found. Pairwise Granger Causality tests results reveal that economic growth Granger-causes a reduction in financial development when domestic credit to GDP ratio is used to proxy financial development. On the other hand, when M3 to GDP is used to proxy financial development, finance precedes growth. These mixed results from one dataset lead us to conclude that the inconclusive results in the literature could partly be attributed to different measures of financial development. In a nutshell, we are justified by the evidence adduced above to argue that finance could promote growth in Botswana via the expansion of the size of the financial intermediary sector.

To the extent that an increase in the size of the financial intermediary sector culminates in economic growth, the paper predicts that financial liberalization which increases competition in the financial system could be in the best interest of the economy of Botswana. However, financial liberalization must be pursued with care because over-liberalization could have dire consequences such as over-lending and careless lending which could destabilize the financial system of Botswana and, in turn, undermine her growth.

Probably, the positive relationship between economic openness and economic growth suggests that pursuit of some economic liberalization that makes the economy of Botswana more open to the outside world is likely to catalyze her economic growth. However, this must be done with tact and circumspection because economic openness could have destabilizing consequences for an economy.

\section{Acknowledgement}

The research is financed by College of Art and Social Sciences of Kwame Nkrumah University of Science and Technology, Kumasi-Ghana. 


\section{References}

Adusei, M. (2012). Financial development and economic growth: is Schumpeter right?" British Journal of Economics, Management \& Trade, 2(3), 265-278.

Adusei, M. (2013). Financial development and economic growth: evidence from Ghana. International Journal of Business and Finance Research, 7(5), 61-76.

Agbetsiafa, D. (2004). The finance-growth nexus: evidence from Sub-Saharan Africa. Savings and Development, 28(3), 271-288.

Akinboade, O.A. (1998). Financial development and economic growth in Botswana: a test for causality. Savings and Development, 22(3), 331-348.

Apergis, N., Filippidis, I., \& Economidou C. (2007). Financial deepening and economic growth Linkages: A Panel Data Analysis. Review of World Economics, 143(1), 179-198. http://dx.doi.org/10.1007/s10290-007-0102-3

Arestis, P., \& Demetriades P.O. (1997). Financial development and economic growth: assessing the evidence. The Economic Journal, 107, 783-799. http://dx.doi.org/10.1111/j.1468-0297.1997.tb00043.x

Beck, T., \& Levine, R. (2002). Stock markets, banks and growth: panel evidence, World Bank Working Paper.

Beck, T., Demirguc-Kunt, A., \& Levine R. (2000).A new database on financial development and structure. World Bank Economic Review, 14, 597-605. http://dx.doi.org/10.1093/wber/14.3.597

Ben Naceur, S., \& Ghazouani, S. (2003). The determinants of stock market development in some MENA region countries: a panel data analysis. Finance Research Working Paper. October 2003.

Bittencourt, M. (2012). Financial development and economic growth in Latin America: is Schumpeter Right? Journal of Policy Modeling, 34(3), 341-355. http://dx.doi.org/10.1016/j.jpolmod.2012.01.012

Bloch, H., \& Tang, S.H.K. (2004). Deep determinants of economic growth: institutions, geography and openness to trade. Progress in Development Studies, 4(3), 245-255. http://dx.doi.org/10.1191/1464993404ps088pr

Brownbridge, M., \& Kirkpatrick, C. (2000). Financial regulation in developing countries, Institute for development policy and management, Working Paper.

Choe, C., \& Moosa I.A. (1999). Financial system and economic growth: The Korean experience. World Development, 27(6), 1069-1082. http://dx.doi.org/10.1016/S0305-750X(99)00042-X

Chukwu, J.O., \& Agu C.C. (2009). Multivariate causality between financial depth and economic growth in Nigeria. African Review of Money Finance and Banking, 7-21. 
De Gregorio, J., \& Guidotti, P. (1995). Financial development and economic growth. World Development, 23(3), 433-448. http://dx.doi.org/10.1016/0305-750X(94)00132-I

Demetriades P.O., \& Hussein K.A. (1996). Does financial development cause economic growth? Time Series Evidence from 16 Countries. Journal of Development Economics, 5(2), 87-411.

Demirguc-Kunt, A., \& Degatriache E. (1998). The determinants of banking crises in developing and developed countries. International Monetary Fund Staff Papers, 45, 81-109. http://dx.doi.org/10.2307/3867330

Demirguc-Kunt, A., \& Detragiache E. (2000). Monitoring banking sector fragility: a multivariate logit approach. World Bank Economic Review, 14, 287-307. http://dx.doi.org/10.1093/wber/14.2.287

Eita J.H., \& Jordaan A.C. (2010). A causality analysis between financial development and economic growth for Botswana. The African Finance Journal, 12(1), 72-89.

Enisan, A.A., \& Olufisayo A.O. (2009). Stock market development and economic growth: evidence from Seven Sub-Sahara African countries. Journal of Economics and Business, 61(2), 162-171. http://dx.doi.org/10.1016/j.jeconbus.2008.05.001

Esso, L.J. (2010). Re-examining the finance-growth nexus: structural break, threshold cointegration and causality evidence from the Ecowas. Journal of Economic Development, 35(3), 57-79.

Ghosh, A., \& Phillips S. (1998). Warning: inflation may be harmful to your growth. IMF Staff Papers, 45(4), 672-710. http://dx.doi.org/10.2307/3867589

Goldsmith, R. W. (1969). Financial structure and development. New Haven, CT: Yale University Press.

Gourinchas, P., Landerretche, O., \& Valde's R. (2001). Lending booms: Latin America and the World. Economia, 1, 47-100.

Hondroyiannis G., Lolos, S., \& Papapetrou E. (2004). Financial markets and economic growth in Greece, 1986-1999.Bank of Greece, Working Papers, No. 17, September.

Kaminsky, G., \& Reinhart C. (1999). The twin crises: the causes of banking and balance of payments problems. American Economic Review, 89, 473-500. http://dx.doi.org/10.1257/aer.89.3.473

King, R., \& Levine R. (1993a). Finance and growth: Schumpeter might be right. Quarterly Journal of Economics, 153, 717-738. http://dx.doi.org/10.2307/2118406

King, R., \& Levine R. (1993b). Finance, entrepreneurship, and growth: theory and evidence. Journal of Monetary Economics, 32, 513-542. http://dx.doi.org/10.1016/0304-3932(93)90028-E

Levine, R., \& Zervos S. (1996). Stock market development and long-run growth. World Bank 


\section{Macrothink}

Econ Review, 10(2), 323-339. http://dx.doi.org/10.1093/wber/10.2.323

Levine, R., Loayza, N., \& Beck T. (2000). Financial intermediation and growth: causality and causes. Journal of Monetary Economics, 46, 31-77. http://dx.doi.org/10.1016/S0304-3932(00)00017-9

Liang, Q., \& Teng J.Z. (2006). Financial development and economic growth: evidence from China. China Economic Review, 17(4), 395-411.

Loayza, N.V., \& Rancie're R. (2006). Financial development, financial fragility, and growth. Journal of Money, Credit and Banking, 38(4), 1051-1076. http://dx.doi.org/10.1353/mcb.2006.0060

Luintel, R., \& Khan M. (1999). A quantitative re-assessment of the finance-growth nexus: evidence from a multivariate VAR. Journal of Development Economics, 60, 381-405. http://dx.doi.org/10.1016/S0304-3878(99)00045-0

Ndako, U.B. (2010). Financial development and economic growth: evidence from Nigeria. The IUP Journal of Financial Economics, 8(4), 37-59.

Ndebbio, J E U. (2004). Financial deepening, economic growth and development: evidence from selected SSA countries. Research Papers, African Economic Re-search Consortium, No. RP_142.

Odhiambho N. M. (2004). Financial development and economic growth in South Africa, Department of Economics, University of Fort Hare, South Africa.

Odhiambho N.M. (2005). Financial development and economic growth in Tanzania: A dynamic causality test. African Finance Journal, 7, Part 1.

Odhiambo, N.M. (2009). Finance-growth nexus and inflation dynamics in Kenya: an empirical investigation. Savings and Development, 33(1), 7-25.

Odhiambo, N.M. (2010). Finance-investment-growth nexus in South Africa: an ARDL-bounds testing procedure. Econ Change Restruct, 43, 205-219. http://dx.doi.org/10.1007/s10644-010-9085-5

Quartey, P., \& Prah F. (2008). Financial development and economic growth in Ghana: is there a causal link? The African Finance Journal, 10(1), 28-54.

Rioja, F., \& Valev N. (2004). Does one size fit all? a reexamination of the finance and growth relationship. Journal of Development Economics, 74, 429-47. http://dx.doi.org/10.1016/j.jdeveco.2003.06.006

Rousseau, P. L., \& Wachtel P. (2000). Equity markets and growth: cross-country evidence on timing and outcomes: 1980-1995. Journal of Banking and Finance, 24, 1933- 1957. http://dx.doi.org/10.1016/S0378-4266(99)00123-5

Rousseau, P.L., \& Vuthipadadorn D. (2005). Finance, investment and growth: time series evidence from 10 Asian Economies. Journal of Macroeconomics, 27, 87-106. 
http://dx.doi.org/10.1016/j.jmacro.2003.09.004

Saci, K., Giorgioni, G., \& Holden K. (2009). Does financial development affect growth? Applied Economics, 41, 1701-1707. http://dx.doi.org/10.1080/00036840701335538

Schneider, M., \&Tornell, A. (2004). Balance sheet effects, bailout guarantees and financial crises. Review of Economic Studies, 71, 883-913. http://dx.doi.org/10.1111/j.1467-937X.2004.00308.x

Schumpeter J. A. (1911). The theory of economic development. Cambridge, MA, Harvard University Press.

Tran, A. T. (2008). Financial development and economic growth in the Case of Vietnam. Journal of International Business and Economics, 8(2), 135-153.

Wood, A. (1993). Financial development and economic growth in Barbados, causal evidence. Savings and Development, 17(4), 379-390.

Zang, H., \& Kim Y.C. (2007). Does financial development precede growth? Robinson and Lucas might be Right. Applied Economics Letters, 14, 15-19. http://dx.doi.org/10.1080/13504850500425469

\section{Copyright Disclaimer}

Copyright reserved by the author(s).

This article is an open-access article distributed under the terms and conditions of the CreativeCommons Attribution license (http://creativecommons.org/licenses/by/3.0/). 